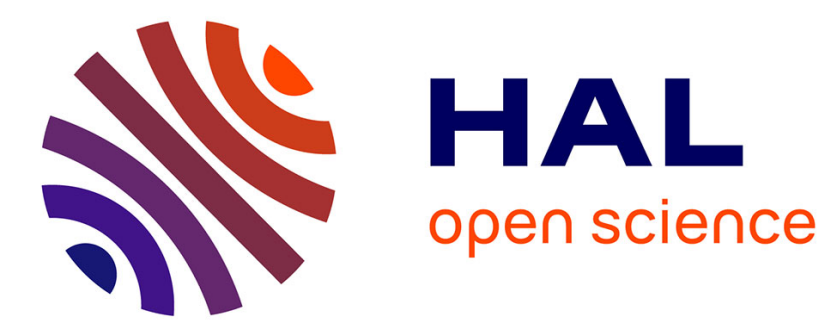

\title{
New Markers in Anopheles gambiae Salivary Glands After Plasmodium berghei Infection.
}

Aleksandar Zocevic, Annick Carmi-Leroy, Jean Sautereau, Jacques d'Alayer, P. Lenormand, J.-C. Rousselle, A. Namane, Valérie Choumet

\section{To cite this version:}

Aleksandar Zocevic, Annick Carmi-Leroy, Jean Sautereau, Jacques d'Alayer, P. Lenormand, et al.. New Markers in Anopheles gambiae Salivary Glands After Plasmodium berghei Infection.. VectorBorne and Zoonotic Diseases, 2013, epub ahead of print. 10.1089/vbz.2012.0964 . pasteur-00771519

\section{HAL Id: pasteur-00771519}

\section{https://hal-pasteur.archives-ouvertes.fr/pasteur-00771519}

Submitted on 10 Jan 2013

HAL is a multi-disciplinary open access archive for the deposit and dissemination of scientific research documents, whether they are published or not. The documents may come from teaching and research institutions in France or abroad, or from public or private research centers.
L'archive ouverte pluridisciplinaire HAL, est destinée au dépôt et à la diffusion de documents scientifiques de niveau recherche, publiés ou non, émanant des établissements d'enseignement et de recherche français ou étrangers, des laboratoires publics ou privés. 


\title{
New Markers in Anopheles gambiae Salivary Glands After Plasmodium berghei Infection
}

\author{
Aleksandar Zocevic, Annick Carmi-Leroy, Jean Sautereau, Jacques d'Alayer, ${ }^{2}$ P. Lenormand, ${ }^{3}$ \\ J.-C. Rousselle, ${ }^{3}$ A. Namane, ${ }^{3}$ and Valérie Choumet ${ }^{1}$
}

\begin{abstract}
In malaria, mosquito saliva and salivary glands play central roles in the multi-faceted interactions that occur among the parasite, its vector, and its host. Analyzing the processes involved in the survival and maintenance of the Plasmodium parasite in mosquito organs, and in its transmission into vertebrate hosts, may lead to the identification of new molecular targets for parasite control. We used comparative two-dimensional gel polyacrylamide electrophoresis (2D-PAGE), surface-enhanced laser desorption/ionization time-of-flight mass spectrometry (SELDI-TOF-MS), and high-performance liquid chromatography (HPLC), followed by Edman sequencing, to study saliva and salivary gland samples from Anopheles gambiae mosquitoes infected or not with Plasmodium berghei. Quantitative 2D-PAGE profile analysis showed that the intensities of seven spots were affected by the presence of the parasite in the salivary glands. Most of the proteins identified possessed a signal peptide. SELDI-TOF-MS revealed 32 proteins/peptides whose peak intensities differed between the Plasmodiuminfected and non-infected control groups. Quantitative comparison of HPLC profiles of low-molecular-weight components from salivary gland extracts revealed several peptides and proteins with levels that were modulated by parasite infection. The results of these complementary approaches suggest that the infection of female A. gambiae mosquitoes by P. berghei alters the production levels of several salivary gland proteins and peptides, some of which (e.g., protein cE5, B3VDI9_ANOGA, and AGAP008216-PA) are known or predicted to be secreted in saliva and involved in blood feeding.
\end{abstract}

Key Words: Anopheles gambiae-Arthropod saliva-Biomarkers-Plasmodium berghei-Proteomics.

\section{Introduction}

$\mathbf{M}$ ANY OF THE MOST DEVASTATING human diseases are transmitted by blood-feeding arthropods. The African mosquito Anopheles gambiae is the most important vector of human malaria, a parasitic disease that affects $40 \%$ of the population in tropical and subtropical regions. Malaria parasite transmission has been increasing in recent years for several reasons. First, insecticide resistance in mosquitoes has been increasing (Roberts and Andre 1994; Chouaibou et al. 2008; Ranson et al. 2009). Second, resistance to inexpensive drugs in the parasite itself has also been increasing (Price et al. 2004; Dondorp et al. 2009). Innovative new methods of parasite control are therefore needed to prevent transmission and to prevent the spread of malaria. Alternative methods include blocking the parasite in the insect vector. However, this strategy requires further and more detailed information about the interactions among the Plasmodium parasite, the Anopheles mosquito, and the human host. Indeed, mosquito saliva and salivary glands play central roles in these interactions (Rodriguez and Hernandez-Hernandez Fde 2004; Dhar and Kumar 2003; Lombardo et al. 2005).

To interact with vertebrates, blood-feeding arthropods possess modified mouth parts and their salivary glands produce a highly adapted saliva containing components with pharmacological activities that counteract the hemostatic, inflammatory, and immune system responses of the vertebrate host (Ribeiro et al. 1984; Ribeiro 1995; Champagne 2005; Andrade et al. 2005; Titus et al. 2006).

Arthropod salivary glands play a crucial role in the development and transmission of vector pathogens. Indeed, in Plasmodium transmission, either by interacting with molecules within secretory cells (including saliva components), or because they undergo a time-programmed maturation,

\footnotetext{
${ }^{1}$ Unité de Biochimie et de Biologie Moléculaire des Insectes, ${ }^{2}$ Plate-Forme d'Analyse et de Microséquençage des Protéines, and ${ }^{3}$ Plate-forme de Protéomique, PF3, Institut Pasteur, Paris Cedex, France.
} 
Plasmodium sporozoites in salivary glands are more infective to vertebrate hosts than earlier-stage sporozoites (Matuschewski 2006; Aly et al. 2009). Moreover, the pharmacological activity of arthropod saliva profoundly affects pathogen transmission (Ribeiro et al. 1987; Tabachnick 2000; Titus et al. 2006). Inoculation with Plasmodium via mosquito saliva increases the risk of infection, indicating that some parasites exploit the vector to enhance their development and multiplication in the vertebrate host (Rocha et al. 2004; Donovan et al. 2007). Using proteomic approaches to investigate the effects of Plasmodium sporozoites on salivary protein production is likely to provide insights into the migration and development of the parasite in a key organ for its maturation.

In a previous study, we used a number of complementary proteomic approaches to characterize the salivary gland proteome of $A$. gambiae (Choumet et al. 2007). In addition, we performed comparative analyses of Plasmodium-infected and non-infected salivary glands using two methods: a twodimensional polyacrylamide gel electrophoresis (2D-PAGE)based approach, in which the salivary gland extracts were subjected to a clean-up step, and a non-gel-based technique was used to quantify proteins (isobaric tags for relative and absolute quantitation: iTRAQ). Although we failed to identify any infection-specific markers with the 2D-PAGE-based method, the quantitative comparison performed by iTRAQ allowed us to identify five proteins that had levels that were modulated by Plasmodium infection (Choumet et al. 2007). Moreover, we did not address the putative modulation of salivary gland peptide production in the presence of the parasite. Indeed, several peptides were identified in the sialomes of Anopheles mosquitoes (Arca et al. 2005; Calvo et al. 2007), but the biological functions of most of these are unknown, especially with regard to their possible roles in Plasmodium infection. Salivary gland peptides may indeed play an important role in the cycle of the parasite and its transmission. Indeed, transcriptome analysis of Plasmodiuminfected Anopheles stephensi showed a modulation of expression of several peptides (Dixit et al. 2009). Moreover, comparative analyses of transcriptomes from arbovirusinfected and non-infected arthropod salivary glands have shown induction of peptides with activity against some pathogens (Luplertlop et al. 2011; McNally et al. 2012).

In this study, to identify Plasmodium infection-specific markers, we performed comparative analyses of Anopheles salivary gland crude extracts using 2D-PAGE and surfaceenhanced laser desorption/ionization time-of-flight mass spectrometry (SELDI-TOF-MS). We also analyzed the peptidic fraction of salivary gland extracts using ProteinChip array profiling. HPLC separation followed by sequencing of the peptides contained in infection-altered peaks allowed us to identify several Anopheles salivary gland peptide markers of $P$. berghei infection.

\section{Materials and Methods}

\section{Mosquitoes and Plasmodium infection}

A. gambiae mosquitoes were of a Yaoundé strain (Cameroon) and bred in the CEntre de Production et d'Infection des Anophèles (CEPIA) insectarium. Six-week-old Swiss mice (Janvier) were infected by intraperitoneal (IP) injection with a $P$. berghei strain NK65 expressing the green fluorescence protein (Natarajan et al. 2001). Parasitemia was monitored 4 days after Plasmodium injection in infected mice by examining Giemsa-stained thick blood smears. Mice exhibiting parasitemia at 7 days were considered to be infected. Threeday-old mosquitoes were fed on mice demonstrating 5-10\% parasitized red cells in which gametocyte exflagellation was evident in a drop of blood mixed with PBS and viewed at $40 \times$ magnification. These same conditions were used for the seven infection experiments. Three-day-old control mosquitoes were fed on non-infected rabbit blood. The mosquitoes were maintained on a diet of $10 \%$ sugar.

\section{Salivary gland collection}

Salivary glands were collected from 21-day-old female mosquitoes, infected or not infected with $P$. berghei, 18 days after the blood meal. Infected salivary glands were identified using fluorescence microscopy. After dissection, the salivary glands were placed in a tube containing $100 \mu \mathrm{L}$ of $150 \mathrm{mM}$ sodium chloride ( $\mathrm{NaCl}$ buffer), or a formate buffer consisting of $0.1 \mathrm{M}$ formate ( $\mathrm{pH} 3.5$ ), and $150 \mathrm{mM} \mathrm{NaCl}$ with protease inhibitors. The samples were stored at $-80^{\circ} \mathrm{C}$ until use.

\section{Extract preparation}

The salivary glands stored at $-80^{\circ} \mathrm{C}$ were placed on ice for $1 \mathrm{~h}$. They were sonicated using the following protocol: five runs of $3 \mathrm{~min}$ of 2 -sec-long pulses at $100 \%$ amplitude. The extracts were then centrifuged at $130,000 \mathrm{~g}$ for $30 \mathrm{~min}$ at $4^{\circ} \mathrm{C}$. The supernatants, designated salivary gland extracts (SGE), were stored at $-80^{\circ} \mathrm{C}$.

\section{Determination of protein concentration and sample concentration}

The protein concentration of SGE was determined spectrophotometrically using a ND-1000 Spectrophotometer (Nanodrop, Wilmington, DE). SGE samples were lyophilized, and either resuspended in $20 \mu \mathrm{L}$ of sterile distilled water for immediate use, or stored dried at $-80^{\circ} \mathrm{C}$.

\section{Two-dimensional gel electrophoresis}

SGE samples from several infection experiments were pooled. Three samples of $15 \mu \mathrm{g}$ lyophilized SGE were analyzed for each state: infected and non-infected, and corresponded to biological replicates. Samples containing $15 \mu \mathrm{g}$ of SGE in a volume of $6.7 \mu \mathrm{L}$ were placed on ice for $20 \mathrm{~min}$, then vortexed and centrifuged for $5 \mathrm{sec}$. Then, Benzonase ${ }^{\circledR}$ (SigmaAldrich, St. Louis, MO) was added to a final concentration of $1.2 \%$, and the samples were incubated for $1 \mathrm{~min}$ at $4^{\circ} \mathrm{C}$. The samples were then mixed with $118.3 \mu \mathrm{L}$ of rehydration solution containing $1 \%$ carrier ampholytes ( $\mathrm{pH} 3-10$; Invitrogen, Carlsbad, CA), $7 \mathrm{M}$ urea (Bio-Rad, Hercules, CA), $2 \mathrm{M}$ thiourea (Sigma-Aldrich), 4\% CHAPS (Sigma-Aldrich), $100 \mathrm{mM}$ DTT (Bio-Rad), and 0.002\% bromophenol blue (Sigma-Aldrich). In-gel rehydration was performed using strip holders. The first-dimension separation protocol was conducted on 3-10 non-linear immobilins $(7 \mathrm{~cm})$ as follows: a passive rehydration for $16 \mathrm{~h}$, an active rehydration for $15 \mathrm{~min}$ at $50 \mathrm{~V}, 30 \mathrm{~min}$ at $300 \mathrm{~V}, 30 \mathrm{~min}$ at $1000 \mathrm{~V}$, and $2 \mathrm{~h}$ at $5000 \mathrm{~V}$. The total run was approximately $6.5-7 \mathrm{kV}$-h with a maximum current of $50 \mu \mathrm{A} /$ strip at $20^{\circ} \mathrm{C}$ (Ettan IPGphor II; GE Healthcare, Little Chalfont, U.K.). The strips were then equilibrated for $15 \mathrm{~min}$ in buffer containing $6 \mathrm{M}$ urea (Bio-Rad), $50 \mathrm{mM}$ 
Tris-HCl (pH 8.8; Sigma-Aldrich), 30\% glycerol, 2\% SDS, and $0.002 \%$ bromophenol blue, with the addition of either $1 \%$ DTT (Bio-Rad) for the first step, or $2.5 \%$ iodoacetamide (IAA; Sigma-Aldrich) for the second step. For the second dimension, the strip was loaded on a 1-mm-thick $12 \%$ SDS-PAGE gel without stacking gel, then embedded with $1 \%$ agarose. Gel electrophoresis was performed for $65 \mathrm{~min}$ at $120 \mathrm{~mA} / \mathrm{gel}$ and $200 \mathrm{~V}$. The slab gels were then stained with SYPRO Ruby (Invitrogen).

\section{Analysis of gel patterns}

SYPRO Ruby-stained gels were scanned with a Typhoon 9400 variable-mode imager (GE Healthcare), and the images were compared using ImageMaster 2D Platinum 7 software (GE Healthcare). All spots identified by the software were verified manually by eye. All spots reported were statistically significant according to the statistical tool built into the software (analysis of variance [ANOVA] test with $p<0.05$ ).

\section{Protein identification by mass spectrometry}

After SYPRO Ruby staining, all visible gel bands were excised using the robotic work station ProPic Investigator (Genomic Solutions, Ann Arbor, MI), and the plugs were collected into 96-well plates. The proteins were reduced, alkylated, and digested overnight with modified porcine trypsin (sequencing grade, ratio 1:100; Promega, Madison, WI) at $37^{\circ} \mathrm{C}$ using the ProGest Investigator (Genomic Solutions). The trypsin digests were desalted with $\mathrm{C} 18$ tips ( $\mu$ ZipTip; Millipore, Billerica, MA). Peptides were directly eluted using the ProMS Investigator (Genomic Solutions) into the wells of a 96-well stainless steel MALDI target plate (Applied Biosystems/MDS SCIEX, Foster City, CA) containing $0.5 \mu \mathrm{L}$ of $\alpha$-cyano-4-hydroxy cinnaminic acid (CHCA; $2.5 \mathrm{mg} / \mathrm{mL}$ in $70 \%$ acetonitrile, $30 \% \mathrm{H}_{2} \mathrm{O}$, and $0.1 \%$ trifluoroacetic acid [TFA]).

\section{Mass spectrometry analysis}

Raw data for protein identification were obtained using a 4800 Proteomics Analyzer (Applied Biosystems/MDS SCIEX), and analyzed by GPS Explorer 2.0 software version 3.6 (Applied Biosystems/MDS SCIEX). For positive ion reflector mode spectra, 2000 laser shots were averaged. For MS calibration, autolysis peaks of trypsin $\left([\mathrm{M}+\mathrm{H}]^{+}=842.5100\right.$ and 2211.1046) were used as internal calibrators. Monoisotopic peak masses were automatically determined within the mass range of 800-4000 Da with the signal-to-noise ratio minimum set to 30 . Up to 25 of the most intense ion signals were selected as precursors for MS/MS acquisition, excluding common trypsin autolysis peaks and matrix ion signals. In the MS/MS positive ion mode, 4000 spectra were averaged; the collision energy was $2 \mathrm{kV}$, the collision gas was air, and the default calibration was set using $\mathrm{Glu}^{1}$-fibrinopeptide B $\left([\mathrm{M}+\mathrm{H}]^{+}=570.6696\right)$ spotted onto 13 positions on the MALDI target. Combined peptide mass fingerprint (PMF) and MS/ MS queries were performed using the MASCOT search engine 2.1 (Matrix Science Ltd., London, U.K.), embedded in the GPS Explorer software on the NCBInr database (downloaded on 01/19/2010; 10,348,164 sequences; 3,529,470,745 residues), with the following parameter settings: 50-ppm mass accuracy for MS; trypsin cleavage with one missed cleavage allowed; carbamidomethylation set as fixed modification; oxidation of methionines and formation of Pyro-Glu (N-term E and Nterm Q) were allowed as variable modifications; and MS/MS fragment tolerance was set to $0.3 \mathrm{Da}$. Protein hits with a MASCOT protein score $\geq 83$, and peptide hits with an Ionscore $\geq 53$, each having a GPS Explorer protein confidence index $\geq 95 \%$, were retained for further manual validation.

\section{SELDI-TOF analyses}

Supernatants of infected and non-infected salivary glands from various dissections were spotted on reverse-phase $\mathrm{H} 4$ (hydrophobic surface: $\mathrm{C}_{16}$ ), and weak cation exchanger (CM10: carboxylate) ProteinChip arrays (Bio-Rad). H4 chips retain peptides and proteins containing hydrophobic amino acids, whereas CM10 chips are designed to retain negativelycharged proteins. Prior to sample incubation, $\mathrm{H} 4$ chips were activated with $1 \mu \mathrm{L}$ of $100 \%$ acetonitrile and air dried. SGE samples $(1 \mu \mathrm{g})$ were spotted onto the $\mathrm{H} 4$ chips in duplicate, allowed to dry, and the spots were washed five times for 1 min each with $5 \mu \mathrm{L}$ of MilliQ water. CM10 chips were equilibrated twice for $15 \mathrm{~min}$ with $150 \mu \mathrm{L}$ of $100 \mathrm{mM}$ sodium acetate ( $\mathrm{pH}$ 3.8), using the Bioprocessor (Bio-Rad), and incubated with the same buffer containing $0.1 \%$ Triton X-100 for $20 \mathrm{~min}$ at room temperature. SGE samples $(2 \mu \mathrm{g})$ were spotted onto the CM10 chips in duplicate and incubated for $30 \mathrm{~min}$ at room temperature with shaking (500 rpm). The arrays were washed under stirring for $5 \mathrm{~min}$ with binding buffer containing $0.1 \%$ Triton X-100, and then twice for $5 \mathrm{~min}$ with binding buffer without detergent. Then each spot was quickly washed twice with MilliQ water and allowed to air dry. Finally, $0.7 \mu \mathrm{L}$ of a CHCA (BioRad) solution made by diluting a CHCA-saturated solution containing $50 \%$ acetonitrile and $0.5 \%$ TFA 1:5 in the same acetonitrile/TFA solution was loaded twice onto each spot of each chip (H4 and CM10) and the spots were air dried.

Molecules retained on the surfaces were visualized by reading the spots of each array in a ProteinChip System timeof-flight mass spectrometer (ProteinChip System 4000) using the ProteinChip MS reader software. Each array was read under suitable conditions for low mass (up to $20 \mathrm{kDa}$ ) to scan the spot, and shots were averaged at $810 \mathrm{~nJ}$ laser intensity with automatic data collection protocols in the Peaks (Ciphergen Biosystems Inc., Fremont, CA) software program. Low-mass spectra were calibrated on a mass calibration equation constructed with All-in-1 peptide standard mix of 7 (BioRad). The data obtained were analyzed using Ciphergen Express 3.0.6 software. Variant peaks were defined as those having $p$ values $<0.05$.

\section{Chromatographic comparison of salivary gland peptides}

SGE from non-infected and infected mosquitoes were first separated by gel filtration on Superdex G75 columns (HR $3.3 \times 30 \mathrm{~mm}$ ) in formate buffer on an Ettan LC chromatography apparatus (GE Healthcare). Fractions (100 $\mu \mathrm{L})$ containing peptides having molecular weights lower than $10 \mathrm{kDa}$ were collected, then lyophilized and resuspended in $100 \mu \mathrm{L}$ of $50 \mathrm{mM}$ Tris $\mathrm{HCl}(\mathrm{pH} 8.6)$ containing $0.01 \%$ Tween 20 . Aliquots of $25 \mu \mathrm{L}$ were then injected onto a DEAE column $(150 \times 1.1 \mathrm{~mm})$ linked to a C18 reversed-phase HPLC column $(150 \times 1 \mathrm{~mm})$, and eluted with a $2-70 \%$ acetonitrile gradient in 
$0.1 \%$ TFA. The profiles of the various fractions (both noninfected and infected) were then compared. Peaks having the same elution volume but differing by at least twofold in peak height between the two chromatograms, or being present in only one condition (infected or not), were then sequenced on a protein sequencer (ABI 494; Applied Biosystems). We conducted BLAST analyses to identify the peptides. The molecular weights of the eluted peptides were assessed by SELDI-TOF-MS on a Au ProteinChip array before sequencing.

\section{Results}

\section{Comparative 2D-PAGE}

In a previous 2D-PAGE analysis of desalted SGE (CleanUp kit; BioRad), we were unable to identify any salivary gland protein affected in the presence of $P$. berghei infection. We therefore analyzed non-desalted SGE $(15 \mu \mathrm{g})$ on a non-linear $\mathrm{pH}$ 3-10 immobilin $(7 \mathrm{~cm})$ and designed an electrofocusing separation protocol. Three gels were performed for each condition (21-day-old infected and non-infected female mosquitoes). Differential analysis of the gels with Image Master 2D Platinum 7 revealed six spots that were upregulated and one spot that was downregulated (with a cut-off of 1.8-fold and ANOVA values of $p<0.05$ ) in the SGE from infected mosquitoes (Fig. 1, Supplementary Figure S1, and Supplementary Table S1; see online supplementary material at http://www.liebertonline.com). The MS analysis of the proteins in these seven spots revealed multiple proteins having different putative cell localizations and functions (Table 1 and Supplementary Table S2; see online supplementary material at http://www.liebertonline.com). Most of the proteins identified are secreted and may thus be present in mosquito saliva. In some cases, the same proteins were identified in different spots (Table 1). As shown previously, this may be due to slightly different amino acid sequences, or to different post-translational modifications (Choumet et al. 2007).

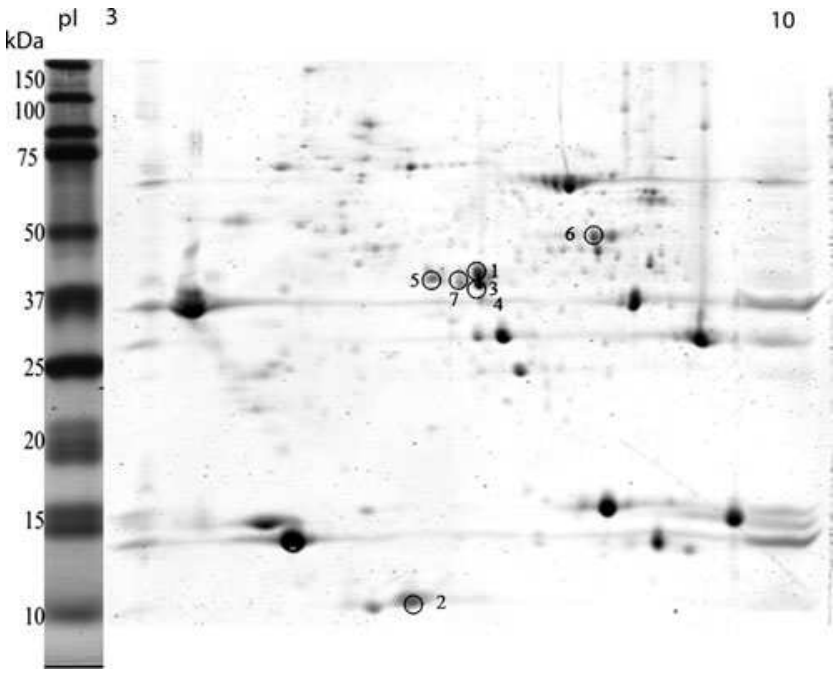

FIG. 1. 2D-PAGE of infected salivary gland extracts. Extracts from salivary glands dissected 18 days after an infected or non-infected blood meal were separated by 2D-PAGE using $\mathrm{pH}$ 3-10 non-linear immobilins for the first dimension, and $12 \%$ acrylamide gel for the second dimension. Protein spots exhibiting differential intensities in infected salivary glands are indicated by number.

\section{SELDI-TOF-MS comparative analysis of low-molecular-weight salivary gland components}

SELDI-TOF-MS is a simple, rapid, high-throughput technique for profiling low-molecular-weight proteins and peptides, including those present in salivary glands. This technology is particularly well suited to identifying peptide markers of infection (De Bock et al. 2010). We examined two different chip surface chemistries: a weak cation exchanger (CM10), and a reversed-phase (H4) chip. Two dissection buffers were tested: $150 \mathrm{mM} \mathrm{NaCl}$ and $0.1 \mathrm{M}$ formate in $150 \mathrm{mM} \mathrm{NaCl}$ (pH 3.5). The formate buffer was selected for its low $\mathrm{pH}$, which decreases the strength of interactions between peptides and high-molecular-weight proteins. We detected multiple proteins having prominent peak intensities between 1000 and 18,000 m/z in infected and non-infected SGE. Figure 2 shows the profiles of infected and non-infected SGE dissected in formate buffer and separated on the ProteinChip surface (CM10). The selected proteins that varied in abundance with respect to infection status are listed in Table 2 according to their $\mathrm{m} / \mathrm{z}$ ratio, the surface on which they were detected, and the dissection buffer used to prepare the extract. Altogether, the two different chip surfaces allowed us to identify 38 unique SGE polypeptides having molecular weights between 1067 and 18,917 $\mathrm{Da}$, and had abundance levels that were affected by Plasmodium infection.

Most of the peaks containing proteins that were less abundant in infected SGE than in non-infected SGE were identified using the CM10 chip, which proved to have the most efficient surface for identifying infection markers. We observed only a few overlaps for the resolved peaks $(\mathrm{m} / \mathrm{z})$ among the two array surfaces and the two dissection buffers, which indicated that the different surface chemistries resolved complementary protein spectra. The formate dissection buffer allowed a greater number of infection-altered peaks to be detected on the two chip surfaces. Thus we used extracts prepared from salivary glands dissected in this buffer to identify the proteins in these peaks in subsequent analyses.

\section{Identification by HPLC of low-molecular-weight salivary gland components whose abundance is affected by $\mathrm{P}$. berghei infection}

Several A. gambiae salivary gland peptides whose abundance levels were modulated by $P$. berghei infection were identified using the SELDI procedure. However, since the amino acid sequences of these peptides could not be determined using this method, we analyzed them by HPLC and Edman sequencing. SGE proteins from non-infected and from $P$. berghei-infected female mosquitoes were first separated according to their molecular weight by gel filtration on Superdex G75, which generated different chromatograms for the two extracts (Fig. 3). Next, the non-infected fractions with molecular weight less than $10 \mathrm{kDa}$ were compared to those of the SGE from infected mosquitoes, and individual peaks were compared between the extracts. The HPLC chromatograms obtained from the B5 fractions of infected and non-infected SGE separated on Superdex G75 show examples of three types of modulation (Supplementary Figure S2; see online supplementary material at http://www.liebertonline.com). The sizes of some peaks in the infected SGE fraction differed with respect to their sizes in the non-infected SGE fraction (e.g., peaks 7 and 13). Some peaks that were present in the infected SGE fraction were 
Table 1. List of Salivary Proteins Detected in Spots Modulated by Plasmodium berghei

\begin{tabular}{|c|c|c|c|c|}
\hline $\begin{array}{l}\text { Spot } \\
\text { number } \\
\text { on } 2 D \text { gel } \\
\text { (as shown } \\
\text { in Fig. 1) }\end{array}$ & $\begin{array}{l}\text { Protein } \\
\text { identification, } \\
\text { name (accession } \\
\text { number) }\end{array}$ & Comments & $\begin{array}{c}\text { Peptide } \\
\text { count/protein } \\
\text { score/\% coverage }\end{array}$ & $\begin{array}{c}\text { Putative } \\
\text { localization }\end{array}$ \\
\hline 1 & $\begin{array}{l}\text { Salivary gland } \\
\text { 1-like } 3 \text { protein } \\
\text { AGAP000607-PA } \\
\text { (gi|18389895) }\end{array}$ & $\begin{array}{l}\text { Found expressed in saliva by a proteomic approach } \\
\text { (Choumet et al. 2007) }\end{array}$ & $15 / 590 / 53$ & Secreted \\
\hline 1 & $\begin{array}{l}\text { AGAP001374-PA } \\
\text { TRIO protein } \\
\text { ( gi|58396245) }\end{array}$ & $\begin{array}{l}\text { Multidomain protein that binds the lymphocyte activating } \\
\text { receptor transmembrane tyrosine phosphatase; may } \\
\text { orchestrate cell-matrix and cytoskeletal rearrangements } \\
\text { necessary for cell migration }\end{array}$ & $9 / 334 / 28$ & Not known \\
\hline 2 & $\begin{array}{l}\text { gSG6 } \\
\text { (gi|225572581) }\end{array}$ & Blood-feeding (Lombardo et al. 2009) & $7 / 326 / 54$ & Secreted \\
\hline 3 & $\begin{array}{l}\text { Salivary gland } \\
\text { 1-like } 3 \text { protein } \\
\text { AGAP000607-PA } \\
\text { (gi|18389895) }\end{array}$ & & $15 / 764 / 53$ & \\
\hline 4 & $\begin{array}{l}\text { Anti-platelet } \\
\text { protein } \\
\text { B3VDI9_ANOGA } \\
\text { (gi|190576763) }\end{array}$ & Blood-feeding & $4 / 187 / 18$ & Secreted \\
\hline 4 & $\begin{array}{l}\text { AGAP009510-PA } \\
\text { (gi|158288305) }\end{array}$ & Malate dehydrogenase & $6 / 134 / 21$ & Intracellular \\
\hline 5 & $\begin{array}{l}\text { Salivary gland } \\
\text { 1-like } 3 \text { protein } \\
\text { AGAP000607-PA } \\
\text { (gi|18389895) }\end{array}$ & & $8 / 394 / 32$ & Secreted \\
\hline 5 & $\begin{array}{l}\text { AGAP001374-PA } \\
\text { TRIO protein } \\
\text { (gi|58396245) }\end{array}$ & Housekeeping protein & $10 / 568 / 30$ & Not known \\
\hline 6 & $\begin{array}{l}\text { Saglin } \\
\text { AGAP000610-PA } \\
\text { (gi|158288615) }\end{array}$ & $\begin{array}{l}\text { Allows invasion of salivary gland by Plasmodium sporozoites } \\
\text { (Okulate et al. 2007; Gosh, et al. 2009) }\end{array}$ & $26 / 1080 / 55$ & Secreted \\
\hline 6 & $\begin{array}{l}\text { gSG1b protein } \\
\text { AGAP000548-PA } \\
\text { (gi|58380426) }\end{array}$ & $\begin{array}{l}\text { Recognized by sera from travelers in tropical Africa } \\
\text { (Orlandi-Pradines et al. 2007) }\end{array}$ & $9 / 188 / 23$ & Secreted \\
\hline 7 & $\begin{array}{l}\text { Salivary gland } \\
\text { 1-like } 3 \text { protein } \\
\text { AGAP000607-PA } \\
\text { (gi|18389895) }\end{array}$ & & $13 / 462 / 47$ & Secreted \\
\hline
\end{tabular}

absent from the non-infected SGE fraction (e.g., peaks 9 and 17). Finally, some peaks evident in the non-infected SGE fraction (e.g., peak 1) were absent from the infected SGE fraction. Table 3 lists the peptides and proteins identified after four such comparisons. We were unable to obtain amino acid sequences for proteins or peptides in several modulated peaks, probably because the $\mathrm{N}$-termini of these proteins or peptides were blocked. Moreover, several of the peptide sequences could not be related to any protein in a BLAST analysis of protein databases, suggesting that low-molecular-weight salivary gland proteins may be poorly represented in the database. Some of the amino acid sequences identified in individual fractions containing proteins with molecular weights lower than $10 \mathrm{kDa}$ corresponded to proteins having molecular weights greater than $10 \mathrm{kDa}$. This result may be due to protein processing, especially in infected salivary glands.
We found four markers representing three different proteins. One of these, the ce5 protein, was less abundant in infected salivary glands than in non-infected glands. Two peptides that were more abundant in infected salivary glands appeared to be fragments of the same protein: the 30-kDa salivary antigen of $A$. gambiae. This observation confirmed that this $30-\mathrm{kDa}$ protein was the one in spot 4 of the 2D-PAGE differential comparisons that exhibited greater intensity in infected SGE than in non-infected SGE. The third peptide marker matched sequences found in the AGAP008216-PA protein, and in the gSG7 protein (with one amino acid difference).

\section{Discussion}

This work reveals elements of the various processes involved in the growth of Plasmodium parasites in mosquito 

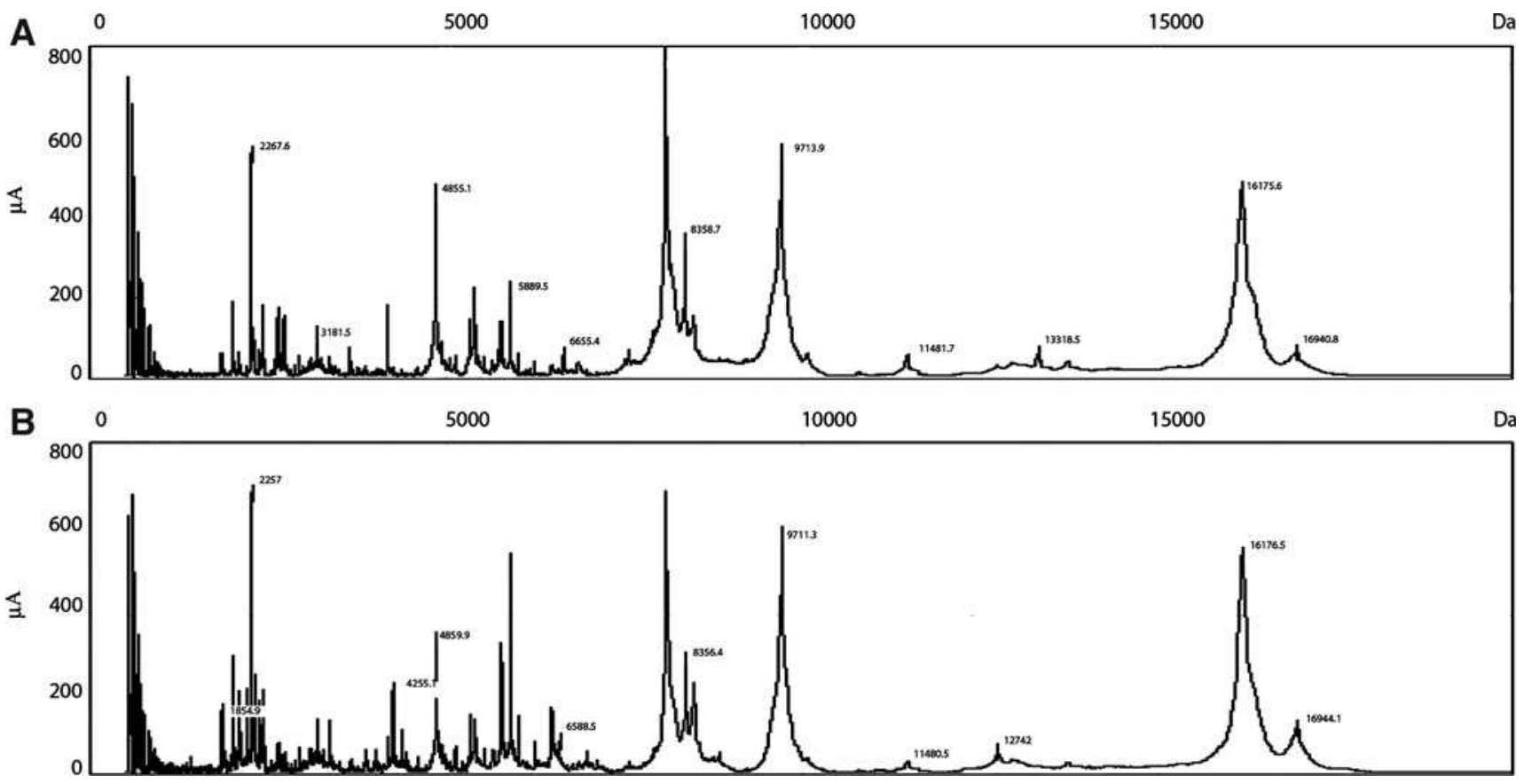

FIG. 2. SELDI-TOF-MS spectra of non-infected and infected salivary gland extracts. The components of non-infected (A) and $P$. berghei-infected (B) salivary glands dissected in formate buffer were separated on a CM10 ProteinChip array as described in the text. Unbound proteins and interfering substances were washed away and matrix was added and allowed to dry. The captured peptides were detected using SELDI-TOF-MS. The normalized masses $(\mathrm{m} / \mathrm{z}$ ) for each peak (in daltons) are shown on the $x$-axis, whereas intensity $(\mu \mathrm{A})$ is plotted on the $\mathrm{y}$-axis. The molecular weights of some of the peaks are indicated. $m / z$ Ratios from different spectra that were within $0.2 \%$ of each other were considered to be potentially the same protein.

salivary glands and in their subsequent transmission to a new host. Our approach identified new molecular targets that might be used for parasite control. A previous transcriptomic approach showed that 37 immune-related genes were upregulated in infected mosquitoes, as well as genes involved in protein transport, lipid metabolism, and energy metabolism. However, this approach indicated that the expression levels of genes implicated in blood feeding were only slightly modified (Rosinski-Chupin et al. 2007). The combination of comparative 2D-PAGE, SELDI-TOF-MS, and HPLC followed by Edman sequencing, allowed us to identify several putative protein and peptide markers. Several types of protein level modulation were detected in the presence of $P$. berghei infection. A. gambiae markers became more abundant, less abundant, disappeared, or appeared. The biological roles of some of these markers are unknown, including the salivary gland 1-like-3 (SG1-like-3) protein, a salivary gland protein of the G1 family of anopheline proteins (Arca et al. 2005). Transcripts of this protein family are found exclusively in or are enriched in the salivary glands of adult females, which suggest that the encoded proteins function in blood feeding. SG1-like-3 protein belongs to the same family as SG1b and TRIO proteins, which were also identified in spots of greater infectionspecific intensity found in this study. Many of the other proteins we identified have known or putative functions; thus it may be possible to interpret the consequences of their modulation.

\section{Markers involved in sporozoite entry or exit}

Two proteins found to be in greater abundance in infected SGE were detected in spot 6 of the 2D-PAGE analysis: saglin and gSG1b. gSG1b was one putative Anopheles saliva protein recognized by sera from travelers in tropical Africa

TABle 2. SELDI Comparison of Infected and Non-Infected Female Mosquito Salivary Gland Components of Molecular Weight Ranging from 1000 to 18,000 Daltons

\begin{tabular}{|c|c|c|c|}
\hline $\begin{array}{l}\text { Dissection } \\
\text { buffer } \backslash \text { chip }\end{array}$ & $H 4$ & CM10 & \\
\hline \multirow[t]{2}{*}{$\mathrm{NaCl}$} & Upregulated peaks & $1067 ; 4411 ; 5645 ; 8475$ & 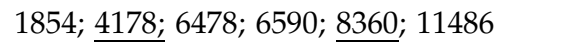 \\
\hline & Downregulated peaks & & $\begin{array}{l}2619 ; 3341 ; 3455 ; 3639 ; 5117 ; \underline{5235 ;} \\
\quad 10086 ; 13327 ; 13741\end{array}$ \\
\hline \multirow[t]{2}{*}{ Formate } & Upregulated peaks & $\begin{array}{l}1846 ; 3180 ; 4086 ; 4178 ; 8095 ; \\
\quad 8359 ; 894 \overline{2 ;} 16195 ; 16365 ; 18917\end{array}$ & $3208 ; 3493 ; \underline{4178 ;}$ 4083; 4789; 5791; 5905 \\
\hline & Downregulated peaks & $2090 ; 2278 ; 2417 ; 2556$ & $4828 ; 5032 ; \underline{5235 ;} ; 5336 ; 5398 ; 15286$ \\
\hline
\end{tabular}

Variant peaks between non-infected and infected conditions were selected when the $p$ value was $<0.05$. Peak molecular weights were obtained after calibration with molecular weight markers. Peaks characterized either on both surfaces or after using different dissection buffers are underlined. 

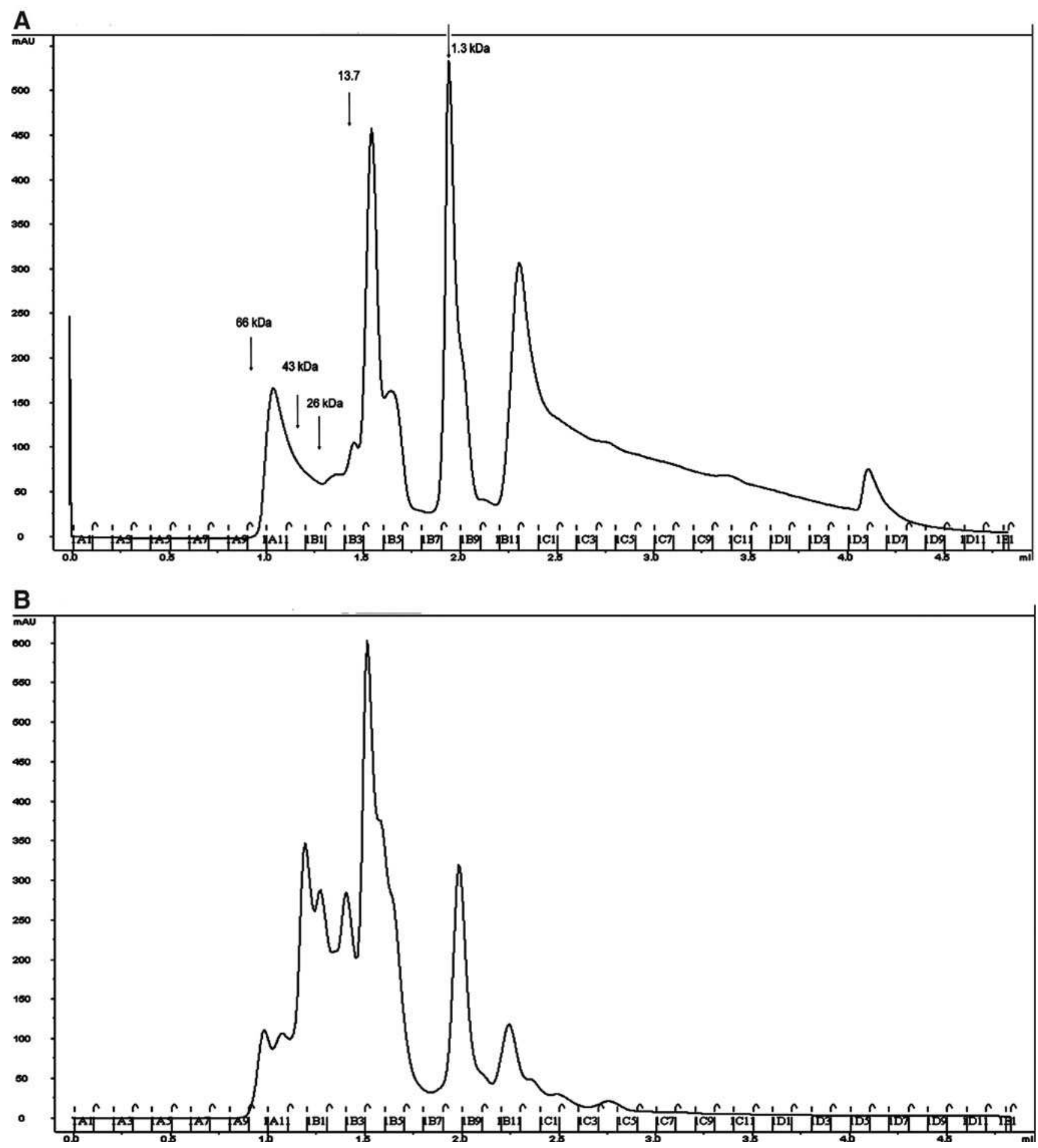

FIG. 3. Separation of non-infected and infected salivary gland extract components by gel filtration. Salivary gland extracts from non-infected (A), and P. berghei-infected (B), mosquitoes were separated on a Superdex G75 column. Molecular weights of standard proteins are indicated. Fractions of $100 \mu \mathrm{L}$ were collected.

(Orlandi-Pradines et al. 2007). This result suggests that gSG1b is indeed a saliva protein; however, its role has not yet been determined. Saglin has been shown to be involved in the invasion of salivary glands by $P$. berghei sporozoites via its interaction with the TRAP protein (Okulate et al. 2007; Ghosh et al. 2009). Consequently, increased production of saglin might facilitate sporozoite entry into and exit from salivary glands.

\section{Markers involved in blood feeding and parasite} transmission

Some of the markers we identified, such as cE5, B3VDI9_ANOGA, and gSG6, are clearly involved in blood feeding, and their modulation may influence this behavior. The cE5 and gSG6 proteins were less abundant in infected 
Table 3. Identification of Markers of Infection by HPLC and Edman Sequencing

\begin{tabular}{|c|c|c|c|c|c|c|}
\hline $\begin{array}{l}\text { Peptide name } \\
\text { and identification } \\
\text { (UniProtKB and } \\
\text { Vectorbase) }\end{array}$ & Peptide sequence & $\begin{array}{l}\text { Type of } \\
\text { modulation } \\
\text { ratio infected/ } \\
\text { non-infected }\end{array}$ & $\begin{array}{c}\text { Type of } \\
\text { experiment }\end{array}$ & $\begin{array}{l}\text { Number of } \\
\text { experiments } \\
\text { where it was } \\
\text { identified }\end{array}$ & $\begin{array}{c}\text { Molecular } \\
\text { weight }(\mathrm{Da})\end{array}$ & Comments \\
\hline $\begin{array}{l}\text { cE5 protein } \\
\text { AGAP008004 }\end{array}$ & HADAPTARDPGR & $\begin{array}{c}\text { Downregulated } \\
0.25 ; 0.4\end{array}$ & $\begin{array}{l}\text { Individual } \\
\text { fractions }\end{array}$ & 2 & 8682 & $\begin{array}{l}\text { Thrombin inhibitor } \\
\text { for mosquito } \\
\text { Homology with } \\
\text { anophelin of } \\
\text { Anopheles albimanus }\end{array}$ \\
\hline $\begin{array}{l}\text { Q9BIH4_ANOGA } \\
\text { AGAP008216 }\end{array}$ & SANHVQQLMKV & $\begin{array}{l}\text { Upregulated } \\
\qquad 4 ; 5 ; 10\end{array}$ & $\begin{array}{l}\text { Pool of fractions } \\
\text { Individual } \\
\text { fractions }\end{array}$ & 3 & 16293 & $\begin{array}{l}\text { Matched to } \\
\text { anophensin, } \\
\text { kallikrein-kinin } \\
\text { system inhibitor } \\
\text { from the salivary } \\
\text { glands of Anopheles } \\
\text { stephensi }\end{array}$ \\
\hline $\begin{array}{l}\text { B3VDI9 } \\
\text { AAL68776 } \\
\text { Q8WR41 }\end{array}$ & $\begin{array}{l}\text { VSTIEKYSKIKE } \\
\text { ADDTSDQE }\end{array}$ & $\begin{array}{l}\text { Upregulated } \\
\quad 4 ; 9\end{array}$ & $\begin{array}{r}\text { Individual } \\
\text { fractions }\end{array}$ & 2 & 25639 & Anti-platelet \\
\hline
\end{tabular}

${ }^{a}$ Modulation of the composition of salivary gland components was compared between infected and non-infected mosquitoes either from a pool of HPLC fractions smaller than $10 \mathrm{kDa}$, or by comparing individual fractions smaller than $10 \mathrm{kDa}$.

The fold modulation observed in infected/non-infected peptide is indicated for each experiment.

mosquitoes, whereas the level of B3VDI9_ANOGA was higher in infected mosquitoes. B3VDI9_ANOGA is a member of the $30-\mathrm{kDa}$ saliva antigen family. Transcripts encoding members of this acidic protein family were detected in a previously reported study of culicine and anopheline mosquito transcriptomes (Calvo et al. 2007). Anti-platelet activity has been attributed to some of the members of the SG1 family that are similar to B3VDI9_ANOGA. Protein cE5 is an analogue of anophelin, a peptide inhibitor of thrombin identified in A. stephensi (Francischetti et al. 1999; Valenzuela et al. 1999; Yoshida et al. 2008). Silencing of this gene using RNAi led to lower blood-feeding capacities and increased probing times (Das et al. 2010), which resulted in increased Plasmodium transmission.

The gSG6 protein levels were lowered by infection, which corroborates our earlier findings (Choumet et al. 2007). Injection of gSG6 dsRNA into adult $A$. gambiae females decreased gSG6 protein levels, increased probing time, and reduced blood-feeding ability (Lombardo et al. 2009), all of which contributed to higher levels of parasite transmission.

Another marker of infection, AGAP008216-PA, is homologous to the gSG7 protein. The sequence of the A. gambiae gSG7 protein is $63.4 \%$ identical to anophensin, which is a kallikrein-kinin system inhibitor from the salivary glands of another malaria vector mosquito, $A$. stephensi (Isawa et al. 2007). Anophensin strongly inhibits the release of bradykinin through inhibition of kallikrein-kinin system activation (Isawa et al. 2007). The anti-inflammatory activity of this protein might be useful to the parasite because Plasmodiuminfected mosquitoes probe for longer times than non-infected mosquitoes, and are therefore more likely to attract the attention of the host (Wekesa et al. 1997). This may enhance the likelihood of parasite transmission.

\section{Conclusions}

By using complementary proteomics approaches, we confirmed that $P$. berghei sporozoites were able modify the compositions of salivary glands and saliva by affecting either gene expression, or the rate at which various proteins are metabolized. Most of these effects would appear to favor parasite penetration, transport, or transmission. The identification of new infection markers will improve our understanding of the complex and crucial relationship between the parasite and the salivary glands of vector mosquitoes. This in turn could lead to new strategies for preventing malaria transmission by targeting its vector.

\section{Acknowledgments}

The work was supported by grants from the Institut Pasteur (Grand Programme Horizontal Anophèle), CNRSPAL +, and the Research Program on Parasitic Diseases Sanofi-Aventis/Ministry for Research. We thank the CEPIA of Institut Pasteur (Dr. Catherine Bourgouin) for mosquito breeding and Plasmodium berghei infections. We thank Dr. Charles Roth and Dr. Paul Brey for their support and advice during this work, and for critical reading of the manuscript.

\section{Author Disclosure Statement}

No competing financial interests exist.

\section{References}

Aly AS, Vaughan AM, Kappe SH. Malaria parasite development in the mosquito and infection of the mammalian host. Annu Rev Microbiol 2009; 63:195-221.

Andrade BB, Teixeira CR, Barral A, et al. Haematophagous arthropod saliva and host defense system: a tale of tear and blood. An Acad Bras Cienc 2005; 77:665-693.

Arca B. An Anopheles gambiae salivary gland promoter analysis in Drosophila melanogaster and Anopheles stephensi. Insect Mol Biol 2005; 14:207-216.

Arca B, Lombardo F, Valenzuela JG, et al. An updated catalogue of salivary gland transcripts in the adult female mosquito, Anopheles gambiae. J Exp Biol 2005; 208:3971-3986. 
Calvo E, Dao A, Pham VM, et al. An insight into the sialome of Anopheles funestus reveals an emerging pattern in anopheline salivary protein families. Insect Biochem Mol Biol 2007; 37:164-175.

Champagne DE. Antihemostatic molecules from saliva of bloodfeeding arthropods. Pathophysiol Haemost Thromb 2005; 34:221-227.

Chouaibou M, Etang J, Brevault T, et al. Dynamics of insecticide resistance in the malaria vector Anopheles gambiae s.l. from an area of extensive cotton cultivation in Northern Cameroon. Trop Med Int Health 2008; 13:476-486.

Choumet V, Carmi-Leroy A, Laurent C, et al. The salivary glands and saliva of Anopheles gambiae as an essential step in the Plasmodium life cycle: a global proteomic study. Proteomics 2007; 7:3384-3394.

Das S, Radtke A, Choi YJ, et al. Transcriptomic and functional analysis of the Anopheles gambiae salivary gland in relation to blood feeding. BMC Genomics 2010; 11:566.

De Bock M, de Seny D, Meuwis MA, et al. Challenges for biomarker discovery in body fluids using SELDI-TOF-MS. J Biomed Biotechnol 2010; 2010:906082.

Dhar R, Kumar N. Role of mosquito salivary glands. Curr Sci 2003; 85:1308-1313.

Dixit R, Sharma A, Mourya DT, et al. Salivary gland transcriptome analysis during Plasmodium infection in malaria vector Anopheles stephensi. Int J Infect Dis 2009; 13:636-646.

Dondorp AM, Nosten F, Yi P, et al. Artemisinin resistance in Plasmodium falciparum malaria. N Engl J Med 2009; 361: 455-467.

Donovan MJ, Messmore AS, Scrafford DA, et al. Uninfected mosquito bites confer protection against infection with malaria parasites. Infect Immun 2007; 75:2523-2530.

Francischetti IM, Valenzuela JG, Ribeiro JM. Anophelin: kinetics and mechanism of thrombin inhibition. Biochemistry 1999; 38:16678-16685.

Ghosh AK, Devenport M, Jethwaney D, et al. Malaria parasite invasion of the mosquito salivary gland requires interaction between the Plasmodium TRAP and the Anopheles saglin proteins. PLoS Pathog 2009; 5:e1000265.

Isawa $\mathrm{H}$, Orito $\mathrm{Y}$, Iwanaga $\mathrm{S}$, et al. Identification and characterization of a new kallikrein-kinin system inhibitor from the salivary glands of the malaria vector mosquito Anopheles stephensi. Insect Biochem Mol Biol 2007; 37:466-477.

Lombardo F, Nolan T, Lycett G, et al. An Anopheles gambiae salivary gland promoter analysis in Drosophila melanogaster and Anopheles stephensi. Insect Mol Biol 2005; 14:207-216.

Lombardo F, Ronca R, Rizzo C, et al. The Anopheles gambiae salivary protein gSG6: an anopheline-specific protein with a blood-feeding role. Insect Biochem Mol Biol 2009; 39:457-466.

Luplertlop N, Surasombatpattana P, Patramool S, et al. Induction of a peptide with activity against a broad spectrum of pathogens in the Aedes aegypti salivary gland, following infection with Dengue virus. PLoS Pathog 2011; 7:e1001252.

Matuschewski K. Getting infectious: formation and maturation of Plasmodium sporozoites in the anopheles vector. Cell Microbiol 2006; 8:1547-1556.

McNally KL, Mitzel DN, Anderson JM, et al. Differential salivary gland transcript expression profile in Ixodes scapularis nymphs upon feeding or flavivirus infection. Ticks Tick Borne Dis 2012; 3:18-26.

Natarajan R, Thathy V, Mota MM, et al. Fluorescent Plasmodium berghei sporozoites and pre-erythrocytic stages: a new tool to study mosquito and mammalian host interactions with malaria parasites. Cell Microbiol 2001; 3:371-379.
Okulate MA, Kalume DE, Reddy R, et al. Identification and molecular characterization of a novel protein Saglin as a target of monoclonal antibodies affecting salivary gland infectivity of Plasmodium sporozoites. Insect Mol Biol 2007; 16:711-722.

Orlandi-Pradines E, Almeras L, Denis de Senneville L, et al. Antibody response against saliva antigens of Anopheles gambiae and Aedes aegypti in travellers in tropical Africa. Microbes Infect 2007; 9:1454-1462.

Price RN, Uhlemann AC, Brockman A, et al. Mefloquine resistance in Plasmodium falciparum and increased pfmdr1 gene copy number. Lancet 2004; 364:438-447.

Ranson $\mathrm{H}$, Abdallah $\mathrm{H}$, Badolo A, et al. Insecticide resistance in Anopheles gambiae: data from the first year of a multicountry study highlight the extent of the problem. Malar J 2009; 8:299.

Ribeiro JM. Blood-feeding arthropods: live syringes or invertebrate pharmacologists? Infect Agents Dis 1995; 4:143-152.

Ribeiro JM, Mather TN, Piesman J, et al. Dissemination and salivary delivery of Lyme disease spirochetes in vector ticks (Acari: Ixodidae). J Med Entomol 1987; 24:201-205.

Ribeiro JM, Rossignol PA, Spielman A. Role of mosquito saliva in blood vessel location. J Exp Biol 1984; 108:1-7.

Roberts DR, Andre RG. Insecticide resistance issues in vectorborne disease control. Am J Trop Med Hyg 1994; 50:21-34.

Rocha AC, Braga EM, Araujo MS, et al. Effect of the Aedes fluviatilis saliva on the development of Plasmodium gallinaceum infection in Gallus (gallus) domesticus. Mem Inst Oswaldo Cruz 2004; 99:709-715.

Rodriguez MH, Hernandez-Hernandez Fde L. Insect-malaria parasites interactions: the salivary gland. Insect Biochem Mol Biol 2004; 34:615-624.

Rosinski-Chupin I, Briolay J, Brouilly P, et al. SAGE analysis of mosquito salivary gland transcriptomes during Plasmodium invasion. Cell Microbiol 2007; 9:708-724.

Tabachnick WJ. Pharmacological factors in the saliva of bloodfeeding insects. Implications for vesicular stomatitis epidemiology. Ann NY Acad Sci 2000; 916:444-452.

Titus RG, Bishop JV, Mejia JS. The immunomodulatory factors of arthropod saliva and the potential for these factors to serve as vaccine targets to prevent pathogen transmission. Parasite Immunol 2006; 28:131-141.

Valenzuela JG, Francischetti IM, Ribeiro JM. Purification, cloning, and synthesis of a novel salivary anti-thrombin from the mosquito Anopheles albimanus. Biochemistry 1999; 38: 11209-11215.

Wekesa JW, Yuval B, Washino RK. Multiple blood feeding by Anopheles freeborni and Culex tarsalis (Diptera:Culicidae): spatial and temporal variation. J Med Entomol 1997; 34: 219-225.

Yoshida S, Sudo T, Niimi M, et al. Inhibition of collagen-induced platelet aggregation by anopheline antiplatelet protein, a saliva protein from a malaria vector mosquito. Blood 2008;111:2007-2014

Address correspondence to: Valérie Choumet Unité Interactions Moléculaires Flavivirus-Hôtes Département de Virologie Institut Pasteur

25 Rue du Dr Roux 75724 Paris Cedex 15 France

E-mail: vchoumet@pasteur.fr 